\title{
OS PLANOS DIRETORES DE BACIA HIDROGRÁFICA E A IRRADIAÇÃO DE EFEITOS SOBRE INSTRUMENTOS DE ORDENAÇÃO TERRITORIAL
}

\section{WATERSHED MASTER PLANS AND THEIR IRRADIATION EFFECTS AT TERRITORIAL ORDERING INSTRUMENTS}

\author{
Délton Winter de Carvalho ${ }^{1}$
}

\begin{abstract}
Resumo
O presente artigo reflete sobre o papel dos Planos Diretores ou Setoriais e sua integração. Neste sentido, apresenta-se uma especial reflexão acerca da influência dos diagnósticos constantes nos Planos de Bacia Hidrográfica, seu poder de produzir restrições urbanísticas, bem como de reduzir a discricionariedade nos processos de planejamento do uso do solo. Trata-se de assunto que, apesar de sua enorme relevância prática, tem sido objeto de pouca reflexão em nossa doutrina jurídica brasileira. Esta função indireta dos Planos de Bacia Hidrográfica, como instrumentos de planejamento territorial e prevenção de riscos de desastres, é enaltecida em virtude do recente incremento na ocorrência de eventos climáticos extremos, com destaque para os processos de inundações urbanas. A complexidade jurídica desta matéria é potencializada pela ausência de regulamentação do novo sistema de gestão de áreas suscetíveis de riscos de desastres (denominados) "naturais". Não obstante a insegurança jurídica trazida pela falta de regulamentação, persiste um dever geral de mapeamento e prevenção de ocupação de áreas de risco, baseando-se tal dever mais no conhecimento empírico dos riscos (por diagnósticos ambientais) do que na desejável internalização de medidas restritivas capazes de compatibilizar Planos Diretores Urbanísticos às disposições insertas nos Planos de Bacia Hidrográfica.
\end{abstract}

Palavras-chave: Direito dos Desastres; Planejamento Urbano; Plano de Bacia Hidrográfica; Plano Diretor Urbanístico; Prevenção.

\begin{abstract}
This essay reflects the role of Master or Sectorial Plan and their integration. On this way, we present a special reflection on the influence of constant diagnoses in the Watershed Plans, its power to produce urban planning restrictions and also how it reduces the discretion in planning land using cases. This subject has got a lack of reflection in Brazilian legal doctrine, although it's huge empirical relevance. These Watershed Plans' indirect functions, as territorial planning instruments and disaster risks prevention is enhanced due to the recent increase in the occurrence of extreme weather events, especially the urban flood processes. The legal complexity of this subject is boosted by the lack of regulation of the new management system for susceptible areas of disaster risk (called) "natural". Despite the legal uncertainty brought by the lack of regulation, a general duty of mapping and prevention of occupation on areas of risk remains, based more on empirical knowledge of risks (by environmental diagnosis) than in the desirable internalization of restricted measures able to reconcile Urbanistic Master Plans to inserts provisions of Watershed Plans.
\end{abstract}

\footnotetext{
${ }^{1}$ Pós-Doutor em Direito Ambiental e dos Desastres pela University of California, Berkeley, EUA. Professor do Programa de Pós-Graduação em Direito da UNISINOS, nível Mestrado e Doutorado. Associado do IDPV Instituto o Direito por um Planeta Verde e da APRODAB - Associação dos Professores de Direito Ambiental do Brasil. Coordenador Regional da APRODAB, Rio Grande do Sul. Membro do Conselho Pedagógico da Escola Superior da Advocacia - ESA/OAB-RS. E-mail: delton@deltoncarvalho.com.br
} 
Revista de Direito da Cidade

vol. 08, no 4. ISSN 2317-7721

DOI: $10.12957 /$ rdc.2016.23805

Keywords: Disaster Law; Prevention; Urban Planning; Urbanistic Master Plan; Watershed Plans. 


\section{INTRODUÇÃO}

O presente texto tem por objeto de investigação uma reflexão acerca da força normativa dos Planos de Bacia Hidrográfica, em especial os efeitos irradiados por estes sobre decisões de ordenação territorial e planejamento urbanístico. Para tal enfrentamento, especial importância recai sobre áreas dotadas de vulnerabilidade física e social, propensas a riscos de desastres em áreas urbanas. Cumpre destacar que a ausência, em nossa doutrina jurídica, de maiores aprofundamentos sobre a temática, apesar de sua inegável relevância para a gestão e planejamentos das cidades em um processo de aumento de eventos climáticos extremos e dos prejuízos (patrimoniais, pessoais e ambientais) destes decorrentes.

A construção de cidades resilientes importa numa necessária atenção a estas vulnerabilidades, onde a concepção político-jurídica das cidades tome em consideração instrumentos de planejamento sustentável, apresentando estes, simultaneamente, conteúdo científico, uso político, eficiência econômica e vinculação jurídica. Dentre estes instrumentos de planejamento, destacam-se os Planos Setoriais, cujos conteúdos específicos envolvem diagnósticos, metas e programas acerca de determinadas funções e competências atribuídas legalmente. Neste sentido, o presente trabalho destaca a importância de uma maior integração e influência recíproca entre os Planos de Bacia Hidrográfica (Lei no 9.433/97), os Planos Diretores Urbanísticos (Lei no 10.257/01) e os Planos de Emergência ou Contingência (Lei no 12.608/12).

Após esta descrição das principais características normativas dos Planos Setoriais, em especial Urbanísticos, de Recursos Hídricos e de Contingência (na Parte 1), passa-se a uma constatação do atual contexto de vulnerabilidade climática e do perfil de desastres climáticos existente no país (Parte 2). Diante deste cenário, há um incremento da relevância jurídica destes Planos e de sua utilização integrada, com o escopo de mitigar riscos de desastres ambientais em ambiente urbanos, destacadamente após a promulgação da Política Nacional de Proteção e Defesa Civil (Lei no 12.608/12).

Em face do perfil dos desastres climáticos ocorridos no Brasil, com grande incidência de inundações, destaca-se um protagonismo das estratégias de ordenação territorial como estratégia de redução de riscos de desastres (Parte 3). Neste sentido, apesar dos Planos Diretores Urbanísticos exercerem uma regulação direta sobre a ordenação e o planejamento territorial local, os diagnósticos ambientais provenientes dos Planos de Bacia Hidrográfica, orientados mais regionalmente, devem exercer algum grau de influência sobre os primeiros. Da mesma sorte, os 
Planos de Contingência servem de orientação para um urbanismo sustentável ou resiliente, indicando diagnósticos de vulnerabilidades e estratégias de resposta a desastres. A grande questão, no entanto, consiste em saber o grau de vinculação exercida pelo conteúdo de tais Planos sobre as decisões de gestão do solo nas cidades, sempre que estas envolverem riscos socioambientais graves. Eis o desafio aceito pelo presente texto...

\section{PLANOS DIRETORES SETORIAIS COMO INSTRUMENTOS DE PLANEJAMENTO JURIDICAMENTE VINCULANTES}

Uma matéria pouco debatida na doutrina jurídica consiste na necessária integração, nos efeitos correlatos e nos conflitos inerentes às assimetrias existentes entre uma possível gama de Planos Setoriais existentes em simultaneidade num mesmo ambiente regional e territorial. Etimologicamente, plano trata-se de uma exposição ordenada dos objetos a serem enfrentados em uma determinada temática. Este decorre do verbo planejar, cujo significado consiste em programar, projetar, determinar objetivos e metas de um empreendimento, como também define a coordenação de meios e recursos para atingi-los (MICHAELIS, 1998, p. 1.635-1.636). Assim, os planos estimulam, construtivamente, a reflexão antecipada, o planejamento preventivo e a escolha estratégica sobre o desenvolvimento desejado. Tais planos têm a função de prevenir, isto é, evitar eventos indesejados previsíveis.

Os planos setoriais, por esta razão, consistem em instrumentos cuja finalidade consiste em planejar as ações em curto, médio e longo prazo, a partir de diagnósticos e cenários prédeterminados, apresentando, necessariamente, um caráter dinâmico para o acompanhamento procedimental do desenvolvimento de um dado setor. Como exemplos de planos setoriais têm-se o Plano Diretor Urbanístico (previsto na Lei n. 10.257/01), Plano Diretor de Bacia Hidrográfica (Lei n. 9.433/97), Plano de Contingência de Proteção e Defesa Civil (Lei n. 12.608/12), dentre vários outros exemplos possíveis.

Os planos setoriais devem ser democraticamente elaborados, consistem em um pacto e, por tal razão tem o dever de serem cumpridos (GRANZIERA, 2006, p. 142). Qualquer plano setorial deve ter como indissociáveis o conhecimento técnico e o envolvimento participativo da coletividade que será alvo do plano (BRASIL; GOVERNOS LOCAIS PELA SUSTENTABILIDADE (ICLEI), 2012, p. 3146). Em linhas gerais, tais planos são constituídos procedimentalmente nas seguintes fases: i) preparatória, ii) de diagnóstico, iii) de prognóstico e iv) de formulação de metas, programas e ações. 
Na fase preparatória há o levantamento de dados e a formulação de um plano de trabalho. Posteriormente, deve haver a elaboração de um diagnóstico, estruturado com dados e informações acerca do perfil da localidade ou das atividades objeto da planificação, tendo este um enfoque eminentemente técnico. Da mesma forma, os planos devem realizar, por meio de estudos técnicos, a construção de prognósticos por cenários futuros (scenario planning), descrevendo hipóteses de situações em possíveis, prováveis, imagináveis ou desejáveis. Tais cenários permitirão a reflexão sobre alternativas futuras, fornecendo referencial para planejamento futuro e a análises de riscos envolvidos. Finalmente, deve haver a formalização e o estabelecimento das metas, com priorização de metas e hierarquização de intervenções desejadas. Para tanto, deve haver a esquematização da implementação do plano, com previsão de critérios para seu monitoramento, avaliação e revisão. Tradicionalmente, é nesta fase (definição de metas, programas e ações) que deve haver um especial resguardo para a participação dos grupos de interesse. Contudo, nada impede que, na fase de diagnóstico, após a coleta de dados e informações, estes possam vir a ser objeto de publicitação para que seja assegurada a participação da coletividade.

Os planos setoriais são instrumentos dotados de um caráter multifacetado, pois apresentam, simultaneamente, conteúdo técnico-científico, servem de orientação para decisões na política, assim como apresentam força normativa (CARVALHO, 2015, p. 65). Tais planos, apesar de deterem uma necessária dinâmica para atualização de seus diagnósticos, metas e objetivos, apresentam um relevante caráter limitador da discricionariedade administrativa.

\section{Planos de Bacia Hidrográfica}

Os chamados Planos de Bacia Hidrográfica ou Planos de Recursos Hídricos "são planos diretores que visam fundamentar e orientar a implementação da Política Nacional de Recursos Hídricos e o gerenciamento dos recursos hídricos" (BRASIL. Lei 9.433, 1997, art. 6ọ). Na condição de planos diretores, estes espelham as mesmas funções de outros planos setoriais, tais como os Planos Diretores Urbanísticos, planejando metas e ordenando o desenvolvimento de determinadas atividades num âmbito específico. Em matéria de Planos de Recursos Hídricos, estes consistem em um dos instrumentos da Política Nacional de Recursos Hídricos, juntamente com o enquadramento dos corpos de água em classes, segundo os usos preponderantes da água; a outorga de direitos de uso de recursos hídricos; a cobrança pelo uso de recursos hídricos; a compensação a Municípios; o Sistema de Informações sobre Recursos Hídricos (BRASIL. Lei 9.433, 1997, art. 5ํ). 
Assim, enquanto planos setoriais consistem em instrumentos de planejamento e ordenação com metas e objetivos, no caso específico do Plano de Recursos Hídricos, estes abrangem uma ou mais bacias hidrográficas. Ao seu turno, a bacia hidrográfica consiste em "área definida topograficamente, drenada por um curso d'água ou um sistema conectado de cursos d'água, de forma que toda vazão efluente seja descarregada através de uma saída única" (KRIEGER; MACIEL; ROCHA; FINATTO; BEVILACQUA, 2008, p. 41).

No que respeita aos Planos de Recursos Hídricos, estes devem ser elaborados tendo por âmbito de abrangência uma determinada bacia hidrográfica, ${ }^{2}$ uma vez se tratar esta da unidade territorial de atuação e planejamento do Sistema Nacional de Gerenciamento de Recursos Hídricos. ${ }^{3}$ De ser gizado o fato da Lei de Política Nacional de Recursos Hídricos (BRASIL. Lei 9.433, 1997) estar estruturada numa organização institucional diversa das competências federativas tradicionais, na qual a unidade territorial consiste no município (atuando ao lado do Distrito Federal, dos Estados e da União). No caso, a Política Nacional de Recursos Hídricos tem a bacia hidrográfica como unidade territorial para gestão dos recursos hídricos. A justificativa para tal escolha na governança dos recursos hídricos se dá pelo fato de que em nada adianta para a tutela jurídica de um curso hídrico um município exercer uma proteção efetiva se outro ente municipal circunvizinho efetua e tolera os mais variados atos de degradação do mesmo corpo hídrico. Desta forma, toda a gestão dos recursos hídricos deve ser realizada a partir desta unidade territorial denominada bacia hidrográfica, sendo composta do curso de água principal e de seus tributários ou afluentes, com uma mesma foz. Portanto, para a gestão plena dos recursos hídricos é fundamental que o objeto do Plano de Recursos Hídricos recaia sobre as múltiplas dimensões correlatas à questão hídrica, abrangendo, assim, as "áreas territorial, hídrica e a área da bacia hidrográfica" (SARLET; MACHADO; FENSTERSEIFER, 2015, p. 377).

Em matéria de recursos hídricos, nos termos constitucionais, não foi atribuída competência legislativa aos municípios, uma vez ser a dominialidade da água restritiva aos Estados e à União, nos termos dos arts. 26, $1{ }^{4}{ }^{4}$ e $20,111,{ }^{5}$ da Constituição Federal, respectivamente. Já no que toca à

\footnotetext{
${ }^{2}$ Conforme art. 8o da Lei no 9.433 (BRASIL, 1997): "Os planos de recursos hídricos serão elaborados por bacia hidrográfica, por estado e para o País".

${ }^{3}$ Conforme art. 1ํ, V da Lei no 9.433 (BRASIL, 1997): "a bacia hidrográfica é a unidade territorial para a implementação da Política Nacional de Recursos Hídricos e atuação do Sistema Nacional de Gerenciamento de Recursos Hídricos".

${ }^{4}$ Art. 26. Incluem-se entre os bens dos Estados: I - as águas superficiais ou subterrâneas, fluentes, emergentes e em depósito, ressalvadas, neste caso, na forma da lei, as decorrentes de obras da União. (BRASIL, Constituição Federal, 1988).
} 
competência administrativa dos municípios para o gerenciamento de recursos hídricos, tem-se a competência ambiental comum, nos termos do art. $23^{6}$ do texto constitucional. Já na Lei de Política Nacional de Recursos Hídricos há a previsão, no art. $31,^{7}$ de que a implementação da Política Nacional de Recursos Hídricos cabe ao Poder Executivo Municipal, promovendo a integração das políticas locais de saneamento básico, de uso, ocupação e conservação do solo e de meio ambiente com as políticas federal e estaduais de recursos hídricos.

Apesar dos Comitês de Bacia Hidrográfica se situarem numa dimensão de parlamento das águas, com a Agência sendo a entidade executiva, aqueles se tratam de órgãos colegiados com atribuições normativas, deliberativas e consultivas a serem exercidas na bacia hidrográfica de sua competência (CONSELHO NACIONAL DE RECURSOS HÍDRICOS, Resolução 5, 2000, art. 1o, §1으). Os Comitês de Bacia Hidrográfica têm a função de parlamento das águas, exercendo sua atuação i) na totalidade de uma bacia hidrográfica; ii) na sub-bacia hidrográfica de tributário do curso de água principal da bacia, ou de tributário desse tributário; ou de iii) grupo de bacias ou sub-bacias hidrográficas contíguas (BRASIL. Lei 9.433, 1997, art. 37). Dentre as competências destes Comitês, em sua área de atuação, encontram-se atos de primordialmente de parlamento. ${ }^{8}$ Para o presente texto, merece destaque a competência dos Comitês para "aprovar o Plano de Recursos Hídricos da bacia" (BRASIL. Lei 9.433, 1997, art. 38, III), sendo este Plano elaborado pela respectiva Agência de Águas (BRASIL. Lei 9.433, 1997, art. 44, X) ou quem estiver no exercício administrativo executivo correspondente. A aprovação do Plano é uma das atribuições mais importantes dos Comitês

\footnotetext{
${ }^{5}$ Art. 20. São bens da União: [...] III - os lagos, rios e quaisquer correntes de agua em terrenos de seu domínio, ou que banhem mais de um Estado, sirvam de limites com outros países, ou se estendam a território estrangeiro ou dele provenham, bem como os terrenos marginais e as praias fluviais. (BRASIL, Constituição Federal, 1988).

${ }^{6}$ Art. 23. É competência comum da União, dos Estados, do Distrito Federal e dos Municípios. (BRASIL, Constituição Federal, 1988).

${ }^{7}$ Art. 31. Na implementação da Política Nacional de Recursos Hídricos, os Poderes Executivos do Distrito Federal e dos municípios promoverão a integração das políticas locais de saneamento básico, de uso, ocupação e conservação do solo e de meio ambiente com as políticas federal e estaduais de recursos hídricos. (BRASIL. Lei 9.433, 1997).

${ }^{8}$ Art. 38. Compete aos Comitês de Bacia Hidrográfica, no âmbito de sua área de atuação: I - promover o debate das questões relacionadas a recursos hídricos e articular a atuação das entidades intervenientes; II arbitrar, em primeira instância administrativa, os conflitos relacionados aos recursos hídricos; III - aprovar o Plano de Recursos Hídricos da bacia; IV - acompanhar a execução do Plano de Recursos Hídricos da bacia e sugerir as providências necessárias ao cumprimento de suas metas; $\vee$ - propor ao Conselho Nacional e aos Conselhos Estaduais de Recursos Hídricos as acumulações, derivações, captações e lançamentos de pouca expressão, para efeito de isenção da obrigatoriedade de outorga de direito de uso de recurso hídricos, de acordo com os domínios destes; $\mathrm{VI}$ - estabelecer os mecanismos de cobrança pelo uso de recursos hídricos e sugerir os valores a serem cobrados; VII - (vetado); VIII - (vetado); IX - estabelecer critérios e promover o rateio de custo das obras de uso múltiplo, de interesse comum ou coletivo. (BRASIL. Lei 9.433, 1997).
} 
(MACHADO, 2015, p. 582). Da mesma forma, o Comitê que aprova o Plano fica também com as funções de acompanhar a execução deste pelas agências e demais entidades, tratando-se de um “acompanhamento dinâmico" (MACHADO, 2015, p. 583).

As agências, por seu turno, exercem a função executiva técnico-administrativa, ou nos termos expressos da lei, "função de secretaria executiva" (BRASIL. Lei 9.433, 1997, art. 41) de um ou vários comitês de bacia. Note-se que a legislação adotou o regime da administração pública indireta, por meio de agências reguladoras, cuja finalidade consiste em exercer uma regulação do mercado mais orientada tecnicamente e próxima do mercado regulado. As agências de regulação, como modelo de governança de setores da economia por parte do Estado, foram instituídas no Brasil para substituírem as burocracias ministeriais, sendo conduzidas por pessoas indicadas pelo Executivo em bases de conhecimento técnico e competência administrativa, aprovadas pelo Senado, devendo exercer mandato em nome do interesse público e dos consumidores. Para tanto, tais serviços devem ser controlados e executados com seriedade, eficiência e universalização (CARDOSO, 1998, p. 10). As agências reguladoras, no modelo introduzido no Brasil, apresentam quatro características:

i. Independência decisória do órgão administrativo colegiado;

ii. Ampliação do poder regulamentar de órgãos que compõem a administração indireta;

iii. Realização do interesse público a partir, principalmente, dos princípios da livre concorrência e da defesa do consumidor e do princípio da eficiência na administração pública; e

iv. Adoção de mecanismos de accountability ${ }^{9}$ e controle social da prestação de serviços públicos (FARIA, 2002, p. 58).

Contudo, nota-se uma grande dificuldade no Estado brasileiro para a implementação plena deste sistema, a fim de tornar a gestão hídrica mais eficiente e promover o necessário deslocamento das decisões de uma ceara preponderantemente política para decisões conformadas mais tecnicamente. Portanto, as agências exercem sua competência ${ }^{10}$ no sentido de

\footnotetext{
${ }^{9}$ Ideia ligada à noção de possível responsabilização e responsabilidade com dever de prestação de contas (FARIA, 2002, p. 24).

${ }^{10}$ Art. 44. Compete às Agências de Água, no âmbito de sua área de atuação: I - manter balanço atualizado da disponibilidade de recursos hídricos em sua área de atuação; II - manter o cadastro de usuários de recursos hídricos; III - efetuar, mediante delegação do outorgante, a cobrança pelo uso de recursos hídricos; IV analizar e emitir pareceres sobre os projetos e obras a serem financiados com recursos gerados pela cobrança pelo uso de recursos hídricos e encaminhá-los à instituição financeira responsável pela administração desses recursos; $\vee$-acompanhar a administração financeira dos recursos arrecadados com a cobrança pelo uso de recursos hídricos em sua área de atuação; $\mathrm{VI}$ - gerir o Sistema de Informações sobre Recursos Hídricos em sua área de atuação; VII - celebrar convênios e contratar financiamentos e serviços para execução de suas competências; VIII - elaborar a sua proposta orçamentária e submetê-la à apreciação do respectivo ou respectivos Comitês de Bacia Hidrográfica; IX - promover os estudos necessários para a
} 
servir de secretaria executiva, a fim de fornecer suporte técnico e gerencial aos respectivos Comitês de Bacia.

\section{Planos Diretores Urbanísticos}

O Plano Diretor Urbanístico consiste em instrumento básico da política de desenvolvimento e expansão urbana, elaborado por lei municipal específica, integrante do planejamento territorial do município e que deve abranger todo o território municipal. Este instrumento regula as atividades e empreendimentos a serem executados no território de um dado município, com escopo de ordenação e orientação dos usos e ocupação do solo para o bem-estar de seus habitantes. Obrigatórios para municípios com mais de 20.000 (vinte mil) habitantes, os Planos Diretores Urbanísticos também são exigidos de municípios em cidades incluídas no cadastro nacional de Municípios com áreas suscetíveis à ocorrência de deslizamentos de grande impacto, inundações bruscas ou processos geológicos ou hidrológicos correlatos. ${ }^{11}$

A competência constitucional para legislar em matéria de ordenamento territorial é exclusiva dos municípios apenas quando se tratar de interesse local, ${ }^{12}$ sendo suplementar em casos pertinentes a Direito Urbanístico. ${ }^{13} \mathrm{O}$ município é o executor da política de desenvolvimento

gestão dos recursos hídricos em sua área de atuação; $X$ - elaborar o Plano de Recursos Hídricos para apreciação do respectivo Comitê de Bacia Hidrográfica; XI - propor ao respectivo ou respectivos Comitês de Bacia Hidrográfica: a) o enquadramento dos corpos de agua nas clases de uso, para encaminhamento ao respectivo Conselho Nacional ou Conselhos Estaduais de Recursos Hídricos, de acordó com o dominio destes; b) os valores a serem cobrados pelo uso de recursos hídricos; c) o plano de aplicação dos recursos arrecadados com a cobrança pelo uso de recursos hídricos; d) o rateio de custo das obras de uso múltiplo, de interesse comum ou coletivo. (BRASIL. Lei 9.433, 1997).

${ }^{11}$ Além destes casos, é obrigatório o Plano Diretor para ciudades integrantes de regiões metropolitanas e aglomeraç̃̃es urbanas; onde o poder público municipal pretenda utilizar os instrumentos previstos no $\S 4$ 응 do art. 182 (parcelamento ou edificação compulsórios, imposto sobre propriedade predial e territorial urbana progressivo no tempo e desapropriação com pagamento mediante títulos da dívida pública de emissão previamente aprovada pelo Senado Federal, com prazo de resgate de até dez anos, em parcelas anuais, iguais e sucessivas, assegurados o valor real da indenização e os juros legais) da Constituição Federal; integrantes de áreas de especial interesse turístico; inseridas na área de influência de empreendimentos ou atividades com significativo impacto ambiental de âmbito regional ou nacional, conforme art. 41 da Lei no 10.257 (BRASIL, 2001).

${ }^{12}$ Conforme. art. 30, I da Constituição Federal (BRASIL, 1988): “Compete aos Municípios: I - legislar sobre assuntos de interesse local".

${ }^{13}$ Conforme art. 30, II da Constituição Federal (BRASIL, 1988): “Compete aos Municípios: (...) II - suplementar a legislação federal e a estadual no que couber". 
urbano, ${ }^{14}$ realizando o seu planejamento por meio do Plano Diretor Urbanístico que, por seu turno, deve ser aprovado por lei municipal.

De ser, contudo, frisado que, neste sistema normativo, referida autonomia do município para legislar sobre ordenamento territorial não é absoluta, mas sim relativa, vez que a delimitação da ordenação territorial e a ocupação do solo, orientada pelos Planos Diretores, deve observar as diretrizes gerais fixadas em lei (sendo competência concorrente da União e dos Estados, nos termos do art. 24, I, da Constituição Federal). ${ }^{15}$

Administrativamente, a competência dos municípios consiste em "promover no que couber, adequado ordenamento territorial, mediante planejamento e controle do uso, do parcelamento e da ocupação do solo urbano" (BRASIL, Constituição Federal, 1988, art. 30, VIII). Note-se, uma vez mais, a necessidade de haver interface entre os entes municipais e os entes Estaduais e a União, uma vez que a ação de administrativa municipal de elaboração dos Planos Diretores deve ser realizada observando os zoneamentos ambientais (conforme art. 9ㅇ, IX, da Lei Complementar no 140 (BRASIL, 2011)), estes confeccionados geralmente por Estados e a União.

Assim, os Planos Diretores Urbanísticos e os Municípios sujeitos à sua obrigatoriedade apresentam uma função direta e imediata de ordenação territorial e estabelecimento dos usos do solo. Contudo, como visto, esta autonomia municipal não se faz absoluta, podendo sofrer restrições e limitações indiretas e mediatas, mesmo em matéria territorial e de usos da propriedade.

\section{Dos Planos de Emergência ou Contingência}

No plano constitucional, a competência privativa para legislar sobre defesa civil é da União (art. 22, XXVIII), ${ }^{16}$ ao passo que a competência administrativa é exclusiva para planejar e promover a defesa permanente contra as calamidades públicas, em especial secas e inundações (nos termos

\footnotetext{
${ }^{14}$ Art. 182. A política de desenvolvimento urbano, executada pelo Poder Público municipal, conforme diretrizes gerais fixadas em lei, tem por objetivo ordenar o pleno desenvolvimento das funções sociais da cidade garantir o bem-estar de seus habitantes. $\$ 10$ O plano diretor, aprovado pela Câmara Municipal, obrigatório para ciudades com mais de vinte mil habitantes, é o instrumento básico da política de desenvolvimento e de expansão urbana. (BRASIL, Constituição Federal, 1988).

${ }^{15}$ Art. 24. Compete à União, aos Estados e ao Distrito Federal legislar concorrentemente sobre: $\mid$ - direito tributário, financeiro, penitenciário, econômico e urbanístico. (BRASIL, Constituição Federal, 1988).

${ }^{16}$ Art. 22. Compete privativamente à União legislar sobre: [...] XXVIII - defesa territorial, defesa aeroespacial, defesa marítima, defesa civil e mobilização nacional. (BRASIL, Constituição Federal, 1988).
} 
do art. $21, \mathrm{XVIII).}{ }^{17}$ Ainda no texto constitucional, há a previsão de que cabe aos bombeiros militares a execução das atividades de defesa civil, integrando a estrutura dos governos estaduais (art. 144, V , §5으..$^{18}$ No exercício desta competência, a União promulgou a Lei № 12.608/12, que institui a Política Nacional de Proteção e Defesa Civil e cria o Sistema Nacional de Proteção e Defesa Civil. Nesta norma, há a atribuição de competências específicas aos três entes federados. Neste sentido, o município pode legislar sobre a matéria apenas para viabilizar a execução da Política Nacional de Proteção e Defesa Civil (conforme sua competência suplementar do art. 30, II, da Constituição Federal), tendo a sua competência administrativa prevista no art. 8o, I, da Lei no $12.608 / 12 .{ }^{19}$

Neste sentido, os Planos de Contingência devem ser confeccionados em nível nacional (Plano Nacional de Proteção e Defesa Civil, nos termos do art. 6으, VIII e $\S 1$ 으, da Lei no 12.608 (BRASIL, 2012)), estadual (Plano Estadual de Proteção e Defesa Civil, conforme art. 7o, III, e parágrafo único, Lei № 12.608 (BRASIL, 2012)) e municipal (art. 8o, XI, Lei № 12.608 (BRASIL, 2012), e art. 3--A, §2ํㅡ, II, da Lei no 12.340 (BRASIL, 2010)). Neste último caso, os planos se restringem àqueles municípios inscritos no cadastro nacional de municípios com áreas suscetíveis à ocorrência de deslizamentos de grande impacto, inundações bruscas ou processos geológicos correlatos.

O Plano de Emergência ou Contingência para desastres consiste em verdadeiros estudos de planejamento desenhados para minimizar o impacto e a vulnerabilidade quando se tem a ocorrência de um desastre, além de exercer a função de facilitar os esforços de reconstrução (BINDER, 2002, p. 791). Estes planos não apenas devem orientar as ações de resposta, como tem a fundamental importância mitigatória de estabelecer os passos que racionalmente devem ser tomados para minimizar riscos previsíveis, uma vez que estes tenham sua ocorrência. As principais medidas de preparo dizem respeito à elaboração de Planos de Emergência e ao fornecimento de capacitação técnica e operacional. No caso dos primeiros, estes devem englobar atividades referentes a todo o ciclo do desastre, tais como atividades de prevenção, mitigação, preparo, resposta, reabilitação e reconstrução. Os planos são frequentemente criticados por serem estáticos e apenas guias para exercícios de rotina. Contudo, estes apresentam um valor bem mais

17 Art. 21. Compete à União: (...) XVIII - planejar e promover a defesa permanente contra as calamidades públicas, especialmente as secas e as inundações. (BRASIL, Constituição Federal, 1988).

18 Art. 144. A segurança pública, dever do Estado, direito e responsabilidade de todos, é exercida para a preservação da ordem pública e da incolumidade das pessoas e do patrimônio, através dos seguintes órgãos: [...] V - polícias militares e corpos de bombeiros militares. [...] §5으s polícias militares cabem a polícia ostensiva e a preservação da ordem pública; aos corpos de bombeiros militares, além das atribuições definidas em lei, incumbe a execução de atividades de defesa civil. (BRASIL, Constituição Federal, 1988).

${ }^{19}$ Art. 8․ . Compete aos Municípios: I - executar a PNPDEC em âmbito local. (BRASIL, Lei 12.608, 2012). 
importante que consiste em estimular um processo de sua concepção e confecção, exigindo que as organizações não apenas mantenham uma orientação e um planejamento para as ações de resposta, como pensem os desastres antecipadamente (BIRKLAND, 2009, p. 123). Assim como os demais planos setoriais, o Plano de Contingência trata-se de uma orientação para uma reflexão preventiva e construtivista acerca de possíveis cenários futuros e as ações desejáveis para cada um destes. $^{20}$

O padrão de cuidado mínimo exigível diz respeito a riscos racionalmente previsíveis (referentes à construção, design, operação, procedimentos, etc.), aos quais os planos devem se antecipar, prevenir e mitigar falhas e consequências. Estes planos estão diretamente ligados ao padrão profissional de cuidado (professional standard of care), ou seja, o padrão adotado pela técnica e referente a uma determinada área do conhecimento (BINDER, 2002, p. 806). Para tanto, tais planos devem apresentar passos racionais a serem tomados em casos de eventos extremos, sejam eles naturais, mistos ou artificiais. Os planos, ainda, consistem em instrumentos decorrentes de um dever de elaboração estabelecido, por lei ou regulamento, para determinadas atividades. Este dever tem relação com a adoção de um padrão de cuidado razoável e não garantia de sucesso em caso de evento extremo (BINDER, 2002, p. 803-804).

Em outras tintas, cabe esclarecer que, caso o plano tivesse que apresentar uma eficiência plena aos eventos extremos, estar-se-ia diante de um padrão de obrigação de resultado, o que se mostra demasiadamente exigente para eventos catastróficos, frequentemente incertos e com baixas probabilidades. O padrão de segurança aplicável em casos de elaboração de planos de emergência reflete-se no dever de atendimento de um cuidado razoável a ser adotado no design das estratégias de preparo e de resposta de emergência a um dado evento, sem exigir-se uma eficácia plena. Trata-se, portanto, de uma obrigação de meio e não de fim ou resultado (BINDER, 2002, p. 804). Este dever de cuidado, como já referido, deve ser delimitado a partir do padrão proveniente do estado da arte profissional.

Deve, em tais planos, haver, pelo menos, a definição clara i) das funções e competências das organizações envolvidas nas respostas emergenciais; ii) da estrutura e da formação de um gabinete de crise; iii) da identificação dos riscos e das áreas especialmente vulneráveis; iv) do inventário de recursos físicos, humanos e financeiros disponíveis e o procedimento para acesso a estes; v) da localização estratégica de recursos e suprimentos; vi) da determinação e da sinalização de rotas de evacuação e áreas para alojamento temporário dos atingidos; vii) do estabelecimento

20 Para um aprofundamento sobre os Planos de Contigência e sua função jurídica, ver CARVALHO, 2015. 
de uma rede de comunicações internas e de informação pública; viii) das descrições de lições aprendidas com eventos anteriores, e seu respectivo dever de atenção a estes aprendizados, a fim de evitar equívocos recorrentes e estimular a adoção das melhores práticas.

Tais planos podem ser governamentais ou setoriais. Após a promulgação da Lei $n^{\circ}$ 12.608/12, todos os níveis federativos (União, Estados, Distrito Federal e Municípios) devem deter seus respectivos Planos de Proteção e Defesa Civil (BRASIL, Lei 12.608, 2012, art. 6ㅇ, VIII, art. 70, III, art. 8o, XI). Após a promulgação da Política Nacional de Proteção e Defesa Civil (Lei n 12.608/12), a elaboração dos planos de emergência adquiriu a condição de um dever de cuidado normativamente imposto no caso brasileiro, devendo cada ente estatal elaborar o respectivo plano de emergência. Do descumprimento deste dever pode decorrer a responsabilização civil das entidades obrigadas à confecção e implementação dos planos em três contextos: i) na falta de plano de emergência; ii) quando este mostrar-se inadequado; iii) falhas em seguir e aplicar o plano (BINDER, 2002, p. 793). ${ }^{21}$ Assim, atividades de riscos específicos e aquelas submetidas normativamente à necessidade de confecção destes planos devem realizá-los a partir de um padrão de riscos racionalmente previsíveis, desenvolvendo a adoção de estratégias e passos de mitigação e respostas para reagir a estes. ${ }^{22}$

\footnotetext{
${ }^{21}$ Note-se que no contexto do direito comparado, esta responsabilidade civil está vinculada à violação ao padrão de cuidado, estando este ligado a um modelo de responsabilidade civil extracontratual fundada na negligência, equivalente à teoria da culpa em nossa tradição, seja em sua versão civil (atividades privadas) ou por falta do serviço (atividades públicas).

22 Interessante destacar que o Conselho Nacional de Justiça - CNJ, em 13 de junho de 2012, emitiu a Recomendação $n^{\circ}$ 40, cujo conteúdo recomenda aos Tribunais de Justiça dos Estados a elaboração de Planos de Ação para o enfrentamento e solução de situações decorrentes de calamidades e desastres ambientais. Estes têm por objeto situações que tenham uma gravidade que justifique uma mudança operacional no atendimento jurisdicional da comunidade afetada, sempre estando condicionada a sua colocação em prática à decretação de situação de emergência ou estado de calamidade pública. Esta recomendação se faz importante, pois a falta de planejamento do próprio Judiciário em nível local é sempre especialmente preocupante, conforme demonstraram as dificuldades havidas na região serrana do Estado do Rio de Janeiro em 2011 e especialmente em New Orleans, após ser atingida pelo Katrina em 2005. No caso norte americano, o sistema criminal entrou em verdadeiro colapso e inoperância. Em razão deste aprendizado, a Corte Superior do Estado da Lousiana tem, após o Katrina, encorajado as cortes locais a terem um plano e estrutura para antecipar-se a desastres, tais como back-up de computadores e fácil acesso a informações sobre servidores e funcionários das cortes. Assim, as cortes judiciais, preferencialmente em todas as suas instâncias, devem entender e comunicar as suas próprias prioridades e medidas de ação em possível resposta necessária às catástrofes possíveis ou recorrentes localmente. (CARVALHO, 2015).
} 


\title{
VULNERABILIDADE CLIMÁTICA E INTEGRAÇÃO ENTRE PLANOS DE BACIA E DEMAIS PLANOS DIRETORES
}

\author{
O perfil de desastres denominados naturais ${ }^{23}$ no Brasil encontra destacada relação com a
} ocorrência de precipitações de grande intensidade, ocasionando inundações e deslizamentos de massa ${ }^{24}$. Empresas de seguro, por exemplo, já destacam o cenário de incremento das ocorrências de desastres naturais no contexto brasileiro, ao afirmar:

As probabilidades demonstram o incremento da frequência de ocorrência dos desastres naturais e o aumento dos custos destes em termos de vidas humanas e despesas governamentais. [...] O Brasil, tradicionalmente, tem tido muito pouca exposição aos desastres naturais, mas nos últimos 5 anos, a frequência destes eventos, tais como chuvas intensas, enchentes e avalanches, tem aumentado. ${ }^{25}$

Tais fenômenos mostram-se ainda mais graves e impactantes, quando sua incidência tem lugar em zonas urbanas, ocasionando as chamadas inundações urbanas. ${ }^{26}$ Não obstante as persistentes incertezas científicas, as mudanças climáticas i) parecem exercer um destacado papel neste cenário, juntamente com outros fatores de amplificação dos riscos e custos de desastres, tais como ii) as condições econômicas modernas; iii) o crescimento populacional e a tendência demográfica; iv) as decisões acerca da ocupação do solo; v) a infraestrutura verde e construída. ${ }^{27}$

\footnotetext{
${ }^{23}$ Relevante aqui a lição de Daniel Farber no que diz respeito ao termo desastres "naturais". Para o autor, atualmente, estes eventos decorrem, de forma cada vez mais frequente, das alterações climáticas, estas provocadas antropogenicamente (isto é, pela humanidade). De tal forma, o autor propõe a superação da tradicional terminologia desastres "naturais" para desastres climáticos, estando abrangido neste termo um caráter de maior sensibilidade às vulnerabilidades produzidas socialmente e, por isto, uma maior aptidão para descrições causais complexas (FARBER, 2016).

${ }^{24}$ Em números, o cenário de danos humanos é revelador, sendo que, entre 1991 a 2010, de um total de 96.220 .879 (noventa e seis milhões, duzentos e vinte mil e oitocentos e setenta e nove) pessoas afetadas, a estiagem e a seca é o desastre que mais afeta a população no país, sendo a mais recorrente (50,34\%). Contudo, são as inundações bruscas, com 29,56\% das vítimas, que causam maior número de mortes $(43,19 \%)$. (ATLAS BRASILEIRO DE DESASTRES NATURAIS, 2012. p. 28-29).

${ }^{25}$ Conforme declaração do diretor de soluções corporativas da Swiss Re, Fabio Corrias: "Natural disaster will likely become more frequent in Brazil and also more costly in terms of human lives and government expenditures [...]. Brazil has traditionally had a very low exposure to natural disaster, but during the last five years the frequency of events such as heavy rains, floods and avalanches has increased [...]" (RINDEBRO, 2011).

26 "A inundação urbana é provocada fundamentalmente pelo excesso de escoamento superficial, chamado de chuva excedente ou de chuva efetiva, gerado pelo aumento dos índices de impermeabilização do solo e por conseguinte da diminuição dos processos de infiltração e de retenção de água. Quando o volume do escoamento superficial gerado ultrapassa a capacidade de escoamento dos cursos d'água que drenam as cidades, ocorrem as inundações" (BARROS, 2005, p. 228).

${ }^{27}$ Acerca dos fatores de amplificação dos riscos e custos de desastres, ver: FARBER; CHEN; VERCHICK; SUN, 2010, p. 09-73 e CARVALHO; DAMACENA, 2013.
} 
Dentre os diversos fatores responsáveis pela produção de inundações urbanas destacamse, para o presente trabalho, a existência de Planos Diretores Urbanos que não consideram devidamente os aspectos de drenagem de uma bacia hidrográfica, sendo, frequentemente, incompatíveis com a hidrologia e a hidráulica das bacias urbanas. Além disso, há, muitas vezes, uma definição imprópria da área de abrangência de projetos de drenagem, acarretando um fenômeno de transferência de inundações de uma cidade para outra (BARROS, 2005, p. 231). Tais eventos mostram uma constante irradiação de eventos sinergéticos por toda uma região, não se limitando a um dado município. O diagnóstico crescente de eventos climáticos extremos e dos prejuízos patrimoniais, humanos e ambientais correlatos, bem como uma possível contribuição por fatores humanos (decisões políticas, atividades econômicas, políticas públicas equivocadas) vem expandindo e alargando a noção de vizinhança para fins de permitir pedidos de responsabilização civil por danos ou mesmo a adoção de medidas preventivas (obrigações de fazer ou não fazer de cunho antecipatório), quando demonstrada a ação contributiva para o desastre (VERCHICK, 2010, p. 92). A noção de vizinhança para fins de possível conflitualidade jurídica e atribuição de responsabilidades, antes orientada apenas para pessoas com residências ladeadas, hoje encontra um alargamento, permitindo conflitos entre comunidades, intermunicipais ou mesmo entre regiões, em face de feixes causais mais complexos.

Dentre uma série de motivos, um aspecto fundamental à análise da ocupação de áreas de risco e sujeitas a inundações, observa-se um estímulo econômico indesejado para a ocupação destas áreas em detrimento dos serviços ecossistêmicos por estas produzidos. Isso ocorre pelo fato de não serem os serviços ambientais tomados em consideração nos valores da propriedade constituída por áreas prestadoras de importantes serviços ambientais, tais como de drenagem, os benefícios transindividuais oriundos destes serviços (FARBER; CHEN; VERCHICK; SUN, 2010, p. 33). Assim, acaba ocorrendo uma subvaloração mercadológica destas áreas. Este processo de subvaloração econômica destas áreas e seus ecossistemas, estimula a sua ocupação em detrimento de sua manutenção ou usos compatíveis com o resguardo de seus serviços ambientais (de prevenção de desastres).

Áreas alagáveis tendem a ter um valor imobiliário baixo, em virtude de uma tradição mercadológica de não valorar os benefícios difusos produzidos pelos serviços ecossistêmicos inerentes a uma dada propriedade. Além disso, muitas vezes, tais áreas ganham uma atribuição legal de espaço territorial especialmente protegido lato sensu, gerando para o seu proprietário restrições significativas ao uso econômico (justificável em virtude dos ganhos ambientais difusos), 
porém, sem qualquer contraprestação ao proprietário (pagamento por serviços ambientais, isenções tributárias, transferência do direito de construir por exemplo). Este cenário acaba por gerar um estímulo à ocupação do imóvel para funções diversas da sua tutela ambiental.

Em virtude deste processo de subvaloração dos serviços ecossistêmicos, sobretudo aqueles vinculados à prevenção de desastres decorrentes de inundações, estas áreas acabam sendo objeto de um processo de estímulo mercadológico para sua destinação para outras finalidades diversas da manutenção dos seus serviços ecossistêmicos preventivos, ante uma maior expectativa de lucro. Este processo decorre da subavaliação destas áreas (contabilizando negativamente as restrições legais e não atribuindo uma valoração positiva para os benefícios socioambientais difusos) acaba, por seu turno, produzindo expectativa de lucros altos para usos de transformação do ambiente destas áreas (diversos da manutenção dos serviços ecossistêmicos). Neste cenário, muito comum em áreas alagáveis, os incorporadores tendem a ter a expectativa de superar margens normais de lucro imobiliário, urbanizando áreas impróprias para ocupação urbanística (FARBER; CHEN; VERCHICK; SUN, 2010, p. 26-39).

Como já observado em contextos internacionais, em casos como estes, as futuras consequências negativas que irão atingir a propriedade (tais como danos por inundação e deterioração dos recursos) acabam sendo transferidos para terceiros na comunidade (adquirentes) ou futuras gerações de contribuintes (ASSOCIATION OF STATE FLOOD PLAIN MANAGERS (ASFPM), 2007, p. 9) (muitas vezes com a responsabilização civil das municipalidades pelos danos reiterados provocados pela omissão em permitir a urbanização de tais áreas ou em falhar em conter tais danos) (CARVALHO, 2015, p. 131-176). Desta forma, os lucros com a ocupação destas áreas são privatizados e os custos são transferidos a terceiros e, muitas vezes, inclusive, socializados com uma determinada comunidade (municipal, estadual ou federal, dependendo do tamanho do desastre).

Este cenário centraliza a produção normativa em matéria de Direito dos Desastres, principalmente com o núcleo regulatório previsto na Lei de Política Nacional de Proteção e Defesa Civil (Lei no 12.608/12). Conforme já referimos em outros momentos (CARVALHO; DAMACENA, 2013), este marco regulatório mostra-se centralizado em estratégias preventivas de ordenação do solo, com o escopo de centrar a ênfase de uma "primeira geração" de Direito dos Desastres (deveres de prevenção a desastres) no Brasil em instrumentos tendentes ao controle de fenômenos descritos como "deslizamentos de grande impacto, inundações bruscas ou processos geológicos ou hidrológicos correlatos" (BRASIL, Lei 12.340, 2010, art. 3--A). Em virtude da relação 
direta entre os danos decorrentes destes fenômenos climáticos e a ocupação de áreas de risco, a estratégia do Direito brasileiro vem se dando no sentido de enfatizar, pelo menos neste primeiro momento de constituição do Direito dos Desastres no nosso país, em instrumentos e estratégias de ordenação territorial. No caso das inundações, especial destaque deve-se dar às áreas alagáveis e à drenagem urbana.

Digno de destaque que os planos setoriais aqui trabalhados ${ }^{28}$ encontram-se entrelaçados para a gestão preventiva dos desastres integrando a estrutura estratégica da Política Nacional de Proteção e Defesa Civil. Não por outra razão, deve haver a integração dos Planos Setoriais. Neste sentido, digno de destaque a referência feita pela legislação no sentido de "adoção da bacia hidrográfica como unidade de análise das ações de prevenção de desastres relacionados a corpos d'água" (BRASIL, Lei 12.608, 2012, art. 4o, IV). Tal previsão decorre do fato de que os Planos de Bacia Hidrográfica apresentam uma abordagem específica aos recursos hídricos, bem como abrangem uma dimensão regional, diferentemente do Plano Diretor Urbano, cujo âmbito é o ente municipal.

\section{EFEITOS RESTRITIVOS URBANÍSTICOS E AMBIENTAIS DECORRENTES DOS PLANOS DE BACIA HIDROGRÁFICA}

Em virtude do perfil de desastres existente do país, com grande incidência de inundações, sobretudo existentes em zonas urbanas das cidades e regiões metropolitanas, ganha destaque a interface e possíveis conflitos decorrentes da contradição existente entre os Planos Diretores Urbanísticos e os Planos de Recursos Hídricos.

É fundamental que os Planos Diretores Urbanísticos, Planos de Recursos Hídricos e outros planos setoriais devem ser compatíveis, integrados e complementares (BARROS, 2005, p. 247). Como visto anteriormente, a abrangência dos Planos de Bacia recai sobre as múltiplas dimensões correlatas à questão hídrica, envolvendo diagnósticos, metas e objetivos referentes às áreas territorial, hídrica e ambiental compreendida por uma bacia. Em face da própria dimensão territorial dos Planos de Bacia, natural a ocorrência de conflitos entre Planos Diretores e os Planos de Recursos Hídricos, ante a ocorrência de possíveis contradições, omissões e incongruências recíprocas.

\footnotetext{
${ }^{28}$ Plano de Recursos Hídricos (art. 40, IV, Lei no 12.608/12), Plano Diretor Urbanístico (art. 42-A e 42-B, da Lei no 10.257/10) e Plano de Contingência (arts. 6oㅡ, VIII e §1ㅇ; 70, III; 8o, XI, todos da Lei no 12.608/12).
} 
Inegavelmente, a gestão urbana e a ordenação do solo municipal têm um protagonismo no ente municipal que, a partir do Plano Diretor, exerce sua competência e atribuição constitucional de "promover, no que couber, adequado ordenamento territorial, mediante planejamento e controle do uso, do parcelamento e da ocupação do solo" (BRASIL, Constituição Federal, 1988, art. 30, VIII).

No entanto, tal competência e atribuição não é absoluta, uma vez que a competência para legislar é exclusiva em assuntos de interesse local, sendo suplementar em casos pertinentes a Direito Urbanístico. Em outras palavras, não obstante o município ser o executor da política de desenvolvimento urbano (BRASIL, Constituição Federal, 1988, art. 182, §1ํ)), realizando o seu planejamento por meio do Plano Diretor Urbanístico, este deve observar as diretrizes gerais fixadas em lei, sendo estas produzidas de forma concorrente pela União e Estados, nos termos do art. 24, I (Direito Urbanístico), VI (florestas, caça, pesca, fauna, conservação da natureza, defesa do solo e dos recursos naturais, proteção do meio ambiente e controle da poluição) e VII (proteção do patrimônio histórico, cultural, artístico, turístico e paisagístico) da CF, por exemplo. São exemplos destas diretrizes gerais, normas infraconstitucionais urbanísticas como o Estatuto da Cidade (Lei $\mathrm{n}$ 10.257/01) ou ambientais como o Código Florestal Federal (Lei n 12.651/12).

Administrativamente, uma vez mais, há a necessidade de interface entre os entes municipais, os Estaduais e a União, uma vez que a ação de administrativa municipal de elaboração dos Planos Diretores deve ser realizada observando os zoneamentos ambientais (conforme art. 9o, IX, da Lei Complementar no 140/11), estes confeccionados geralmente por Estados e a União.

Assim, os Planos Diretores Urbanísticos e os Municípios sujeitos à sua obrigatoriedade apresentam uma função direta e imediata de ordenação territorial e estabelecimento dos usos do solo. Contudo, como visto, esta autonomia municipal não se faz absoluta, podendo sofrer restrições e limitações indiretas e mediatas, mesmo em matéria territorial e de usos da propriedade.

Por tal razão, é fundamental a delimitação dos efeitos de ordenação territorial irradiados pelo Plano de Recursos Hídricos em casos de conflitos territoriais destes com os Planos Diretores sob pena de uma indesejada insegurança jurídica nos processos de ordenação do solo. Conforme analisado previamente, a competência legislativa e administrativa para ordenação territorial é do ente municipal, desde que observadas as diretrizes gerais previstas pela legislação estadual e federal bem como os zoneamentos ambientais. 
Os instrumentos de planificação territorial inegavelmente assumem uma importante função de gestão dos riscos na medida em que podem impor, de forma direta e imediata, limitações ao uso dos solos e à sua transformação. Desta maneira, estes instrumentos adquirem a finalidade de evitar o aumento da vulnerabilidade e riscos já existentes (PAULA OLIVEIRA; LOPES, 2012, p. 178). As diretivas de planejamento urbanístico orientam as opções planificadoras concretas (PAULA OLIVEIRA; LOPES, 2012, p. 179).

Assim, os riscos e vulnerabilidades de inundações podem ser descritos cartograficamente, podendo compor mapas de riscos, planos de drenagem urbana ou mesmo Planos de Bacia Hidrográfica. O conhecimento de tais riscos pelos municípios, quer por diretrizes gerais ou mesmo zoneamentos confeccionados regionalmente, geram um dever de prevenção de tais riscos, quer em ordem urbanística ou outra qualquer. Este dever exige que o município que tenha em sua área zonas de risco ou áreas que possam ocasionar desastres em outros municípios (áreas de drenagem, zonas de inundação, etc.) tenham a obrigação de "introduzir medidas de proteção contra cheias nos planos municipais" (PAULA OLIVEIRA; LOPES, 2012, p. 180). Contudo, de ser destacado que, a despeito do dever do município em adotar medidas de proteção contra riscos de cheias, em nível de ordenação territorial, a determinação concreta de quais sejam essas medidas, cabe em exclusivo, no âmbito do poder discricionário municipal (PAULA OLIVEIRA; LOPES, 2012, p. 180). Servem, portanto, tais informações de limite a esta discricionariedade, quer por obrigar os municípios a considerar e ponderar os riscos de cheia nas decisões de planejamento da sua responsabilidade quer por identificar, em muitos casos, as medidas a serem adotadas.

\section{A limitação da discricionariedade urbanística municipal em virtude das informações técnicas decorrentes do Plano de Bacia Hidrográfica}

Neste sentir, deve-se analisar a capacidade de Planos de Bacia Hidrográfica imporem restrições urbanísticas, apesar destes não consistirem em Planos Diretores Urbanísticos. Cumpre, por ora, enfrentarmos a matéria de qual instrumento deve preponderar em caso de conflito entre o Plano Diretor Urbanístico de um município, que a título exemplificativo pretende a expansão territorial ou a ocupação de áreas de riscos de desastres, e diagnósticos ambientais existentes em Plano de Bacia Hidrográfica. A matéria é pouco enfrentada pela doutrina, bem como sua solução não encontra resposta sedimentada.

A solução para esta questão deve iniciar a ser dirimida dúvida pela análise do grau de vinculação da administração municipal a tais informações técnicas constantes em mapas de riscos 
ou mesmo Planos de Bacia Hidrográfica no que pertence a existência de riscos de desastres ambientais. Neste sentido, existem duas posições juridicamente coerentes. De um lado, o entendimento de que os planos setoriais seriam meramente elementos de instrução a serem avaliados no processo de confecção de Planos Diretores Urbanísticos, gerando efeitos urbanísticos apenas após a sua integração no planejamento urbanístico. De outro, a defesa de que instrumentos tais como Planos de Bacia Hidrográfica geram efeitos restritivos sobre os Planos Diretores Urbanísticos, vinculando a administração municipal na condição de diretrizes gerais ou zoneamentos ambientais, dependendo do caso (PAULA OLIVEIRA; LOPES, 2012, p. 183).

Inegável, em favor do primeiro entendimento, o fato dos Planos Urbanísticos serem instrumentos específicos para ordenação territorial. No entanto, a recente legislação brasileira adota um sistema em que os Planos de Bacia devem exercer uma irradiação de efeitos sobre os Planos Diretores e a ordenação territorial exercida pela municipalidade, conforme art. 42-A, §2ㅇ da Lei no 10.257 (BRASIL, 2010). Esta influência dos Planos de Bacia sobre os Planos Diretores Urbanísticos, por evidente, exerce uma significativa limitação da discricionariedade do ente legislativo municipal. Apesar de permanecer uma margem de discricionariedade municipal, atinente à questão de como o município irá proteger e utilizar tais áreas, há a exigência (vinculação) de haver uma necessária ponderação sobre a existência de riscos de desastres correlatos à expansão da urbanização e a adoção de limitações urbanísticas proporcionais pelo município. Cumpre esclarecer que, apesar destes deveres municipais de ter que considerar e ponderar os riscos de inundações nas decisões de planejamento territorial de sua responsabilidade, estes se tratam de obrigação de meio e não de resultados (PAULA OLIVEIRA; LOPES, 2012, p. 180). Isso significa dizer que as medidas adotadas devem demonstrar a utilização das melhores técnicas disponíveis no estado da arte, sem, contudo, haver uma necessidade de garantia absoluta de prevenção de desastres, algo que seria demasiadamente exigente para casos de desastres, em face de sua constante complexidade, incertezas correlatas e baixas probabilidades.

Atestando a adoção da necessária influência dos Planos de Bacia sobre a ordenação territorial prevista nos Planos Diretores pelo Direito brasileiro, tem-se a previsão normativa constante no art. 42-A, §2o, Lei no 10.257/10. ${ }^{29}$ Como prevê a legislação brasileira, a existência de

\footnotetext{
${ }^{29}$ Art. 42-A. Além do conteúdo previsto no art. 42, o plano diretor dos Municípios incluídos no cadastro nacional de municípios com áreas suscetíveis à ocorrência de deslizamentos de grande impacto, inundações bruscas ou processos geológicos ou hidrológicos correlatos deverá conter: [...] § 2o O conteúdo do plano
} 
áreas de risco deve ser objeto de mapas de risco, devendo as restrições urbanísticas e territoriais nestes previstas ser internalizadas nos Planos Diretores Urbanísticos. Da mesma forma, Planos de Setoriais, tais como de Bacia Hidrográfica ou mesmo de Drenagem, podem gerar efeitos indiretos sobre o ordenamento territorial municipal, impondo deveres de alterar Planos Diretores.

Uma primeira conclusão nos remete à necessária observação de que os Planos de Bacias recaem sobre a área territorial de uma bacia, não apenas sobre os recursos hídricos, sendo assim, é provável que um planejamento hídrico contenha diagnósticos de áreas especialmente sensíveis a ocorrência de desastres ambientais (áreas de drenagem urbana, áreas de preservação permanente, zona de alagamento), sob uma perspectiva regional.

\section{Deveres de compatibilização do Plano Diretor ao Plano de Bacia Hidrográfica ante a ausência de regulamentação normativa dos cadastros de municípios suscetíveis a desastres}

Cumpre analisar de maneira mais detalhada se, e em que medida, a discricionariedade administrativa do município é afetada pela existência de restrições urbanísticas e territoriais previstas no Plano de Bacia Hidrográfica, em razão da existência de áreas de risco de desastres.

O modelo adotado pela legislação brasileira estabelece a necessidade, em casos de riscos de desastres (especialmente no que diz respeito a ocorrências de deslizamentos de grande impacto, inundações bruscas ou processos geológicos ou hidrológicos correlatos), dos municípios confeccionarem mapas de riscos (BRASIL, Lei 12.340, 2010, art. 3-A, §2ํ, I). Tais restrições devem ser absorvidas pelo Plano Diretor Urbanístico, considerando ser este o instrumento urbanístico de eficácia direta e imediata sobre o ordenamento territorial do município (BRASIL, Lei 10.257, 2001, art. 42-A). Note-se, também, que a legislação de proteção civil também designou relevo da bacia hidrográfica e, consequentemente, aos seus Planos de Bacia sempre que os riscos de desastres estiverem relacionados a corpos d'água. Assim, tanto a cartografia que sustenta a confecção dos mapas de risco, como os diagnósticos ambientais existentes em Planos de Bacia e suas restrições urbanísticas devem exercer uma influência sobre os Planos Diretores Urbanísticos, mediante uma redução considerável da discricionariedade administrativa do município na elaboração destes Planos Urbanísticos.

diretor deverá ser compatível com as disposições insertas nos planos de recursos hídricos, formulados consoante a Lei no 9.433, de 8 de janeiro de 1997. 
Portanto, as informações trazidas pelos Planos de Bacia, via de regra posteriores à confecção dos Planos Diretores vigentes, devem gerar processos de alteração destes. Não por outro motivo, o Estatuto das Cidades, alterado pelo art. 26 da Lei no 12.608 (BRASIL, 2012), no §1으, do art. 42-A, prevê que "o conteúdo do plano diretor deverá ser compatível com as disposições insertas nos planos de recursos hídricos". Trata-se, portanto, de obrigação de meio e não de resultado, atribuindo à municipalidade um dever de ponderar sobre as informações constantes em Planos de Recursos Hídricos e mapas de riscos e adotar as melhores opções urbanísticas para prevenção de desastres.

Tal sistema, contudo, merece uma ressalva. Uma atenta análise interpretativa ao conteúdo das orientações urbanísticas trazidas pela Lei no 12.608/12 e que alteram, principalmente, as Leis no $12.340 / 10$ e 10.257/01, demonstra que tais restrições atingem aqueles municípios que aderiram ou foram incluídos no chamado cadastro de municípios com áreas suscetíveis à ocorrência de deslizamentos de grande impacto, inundações bruscas ou processos geológicos ou hidrológicos correlatos. ${ }^{30}$

Contudo, este sistema normativo encontra-se em verdadeiro risco quanto à sua plena eficácia e normatividade, uma vez que o referido cadastro ainda não foi regulamentado pelo

\footnotetext{
${ }^{30}$ Em especial os arts. 3-A e 3-B, da Lei no 12.340 (BRASIL, 2010); arts. 42-A e 42-B, da Lei no 10.257 (BRASIL, 2010); e art 12, §2ㅇd da Lei o 6.766 (BRASIL, 1979):

Arts. 3o-A e 3o-B da Lei no12.340/10:

Art. 3--A: O Governo Federal instituirá cadastro nacional de municípios com áreas suscetíveis à ocorrência de deslizamentos de grande impacto, inundações bruscas ou processos geológicos ou hidrológicos correlatos, conforme regulamento;

Art. 3o-B: Verificada a existência de ocupações em áreas suscetíveis à ocorrência de deslizamentos de grande impacto, inundações bruscas ou processos geológicos ou hidrológicos correlatos, o município adotará as providências para redução do risco, dentre as quais, a execução de plano de contingência e de obras de segurança e, quando necessário, a remoção de edificações e o reassentamento dos ocupantes em local seguro;

Arts. 42-A e 42-B da Lei no 10.257/2010:

Art. 42-A. Além do conteúdo previsto no art. 42, o plano diretor dos Municípios incluídos no cadastro nacional de municípios com áreas suscetíveis à ocorrência de deslizamentos de grande impacto, inundações bruscas ou processos geológicos ou hidrológicos correlatos deverá conter;

Art. 42-B. Os Municípios que pretendam ampliar o seu perímetro urbano após a data de publicação desta Lei deverão elaborar projeto específico que contenha, no mínimo.

Art. 12, § 2으, da Lei ํo 6.766/79:

Art. 12. O projeto de loteamento e desmembramento deverá ser aprovado pela Prefeitura Municipal, ou pelo Distrito Federal quando for o caso, a quem compete também a fixação das diretrizes a que aludem os arts. 60 e 70 desta Lei, salvo a exceção prevista no artigo seguinte. [...] § 2은 Nos Municípios inseridos no cadastro nacional de municípios com áreas suscetíveis à ocorrência de deslizamentos de grande impacto, inundações bruscas ou processos geológicos ou hidrológicos correlatos, a aprovação do projeto de que trata o caput ficará vinculada ao atendimento dos requisitos constantes da carta geotécnica de aptidão à urbanização".
} 
governo federal, havendo assim a impossibilidade de aplicação plena das restrições urbanísticas previstas na sistemática trazida pela Política Nacional de Proteção e Defesa Civil (Lei no $12.608 / 12)^{31}$

Uma vez mais, faz-se necessário a análise aprofundada, neste momento, sobre este déficit regulamentar. O texto normativo é cristalino ao determinar que "o governo federal instituirá cadastro [...] conforme regulamento" (BRASIL, Lei 12.608, 2012, art. 3-A) Cadastro este que deve ser instituído por meio de Decreto, a partir do poder regulamentar atribuído pela Constituição Federal ao Poder Executivo, nos termos do art. 84, IV. ${ }^{32}$

Para casos como este, a doutrina jurídica brasileira tem entendido que em casos de leis que tenham a previsão de serem regulamentadas para sua aplicação não são exequíveis até que o ato regulamentar seja expedido. Entendimento este, bem representado nas tintas de MEIRELLES (2015, p. 144-145):

As leis que trazem a recomendação de serem regulamentadas não são exequíveis antes da expedição do decreto regulamentar, porque esse ato é conditio juris da atuação normativa da lei. Em tal caso, o regulamento opera como condição suspensiva da execução da norma legal, deixando seus efeitos pendentes até a expedição do ato do Executivo.

O mesmo entendimento é acompanhado por BANDEIRA DE MELLO (2008, p. 348) acrescentando este que:

[...] se uma lei depende de regulamentação para sua operatividade, o Chefe do Executivo não pode paralisar-Ihe a eficácia, omitindo-se em expedir as medidas gerais indispensáveis para tanto. Admitir que dispõe de liberdade para frustrar-Ihe a aplicação implicaria admitir que o Executivo tem titulação jurídica para sobrepor-se às decisões do Poder Legislativo.

Segundo o autor, a omissão em regulamentar consistiria em descumprimento de um dever jurídico, cabendo a impetração de mandado de injunção nos termos do art. 5, LXXI, da

${ }^{31}$ Esta omissão do ente federal em regulamentar a criação do cadastro nacional de municípios com áreas suscetíveis à ocorrência de deslizamentos de grande impacto, inundações bruscas ou processos geológicos ou hidrológicos correlatos já foi objeto de cobrança pelo Ministério Público Federal do Rio de Janeiro, por meio de recomendações, conforme notícia publicada no site do próprio Ministério Público Federal do Rio de Janeiro em 14 de Abril 2014: "O Ministério Público Federal (MPF) expediu duas recomendações para tentar minimizar as consequências de possíveis desastres em áreas de risco no Estado do Rio de Janeiro. A primeira foi direcionada à Secretaria-Executiva da Casa Civil da Presidência da República, que ainda não regulamentou a Lei de Política Nacional de Proteção e Defesa Civil (Lei no 12.608/12). A falta de regulamentação impede, por exemplo, instituir e manter o cadastro nacional de municípios com áreas suscetíveis a deslizamentos e inundações. A segunda recomendação foi direcionada à Agência Nacional de Telecomunicações (Anatel), para regularizar o serviço de emergência 199, o número da Defesa Civil." (MINISTÉRIO PÚBLICO FEDERAL, 2014).

${ }^{32}$ Art. 84. Compete privativamente ao Presidente da República: [...] IV - sancionar, promulgar e fazer publicar as leis, bem como expedir decretos e regulamentos para sua fiel execução. (BRASIL, Constituição Federal, 1988). 
Constituição Federal. ${ }^{33}$ A exceção emanada da jurisprudência, acerca da ineficácia de lei que preveja necessidade de regulamentação não expedida pelo Chefe do Governo, limita-se a casos referentes à obtenção do $\mathrm{FGTS}^{34}$ e direito à greve, ${ }^{35}$ por estarem vinculados a norma constitucional de eficácia direta que prevê o direito dos trabalhadores. Para os demais casos, a regra geral é de que a lei não regulamentada permanece com seus efeitos pendentes no que pertine suas previsões dependentes de regulamentação.

Destarte, apesar de o sistema legislativo pátrio ter adotado um modelo em que os Planos de Bacia vinculam as administrações locais em sua atribuição constitucional de ordenação do solo urbano, devendo haver a compatibilização dos Planos Diretores Urbanísticos às informações e diagnósticos constantes nos Planos de Bacia e Mapas de Risco, a falta de regulamentação do cadastro de municípios suscetíveis a desastres específicos acarreta na manutenção do sistema num modelo mais conservador. Inegável que a omissão regulamentar à criação deste cadastro acarreta numa grave ausência de critérios para determinação dos municípios suscetíveis a desastres, bem como para a formação de um sistema integrado para tratamento globalna direção de um urbanismo sustentável (construção sustentável, mobilidade sustentável e a prevenção de desastres) (NUNES; ROSA; MORAES, 2015, p. 6), mediante a inserção do horizonte futuro na ordenação e planejamento do solo (CARVALHO, 2015, p. 78-79). Há, portanto, para um urbanismo

\footnotetext{
${ }^{33}$ Art. 50 Todos são iguais perante a lei, sem distinção de qualquer natureza, garantindo-se aos brasileiros e aos estrangeiros residentes no País a inviolabilidade do direito à vida, à liberdade, à igualdade, à segurança e à propriedade, nos termos seguintes: [...] LXXI - conceder-se-á mandado de injunção sempre que a falta de norma regulamentadora torne inviável o exercício dos direitos e liberdades constitucionais e das prerrogativas inerentes à nacionalidade, à soberania e à cidadania. (BRASIL, Constituição Federal, 1988).

${ }^{34}$ Recurso extraordinário. Direito do Trabalho. Fundo de Garantia por Tempo de Serviço (FGTS). Cobrança de valores não pagos. Prazo prescricional. Prescrição quinquenal. Art. 70, XXIX, da Constituição. Superação de entendimento anterior sobre prescrição trintenária. Inconstitucionalidade dos arts. 23 , § 50, da Lei 8.036/1990 e 55 do Regulamento do FGTS aprovado pelo Decreto 99.684/1990. Segurança jurídica. Necessidade de modulação dos efeitos da decisão. Art. 27 da Lei 9.868/1999. Declaração de inconstitucionalidade com efeitos ex nunc. Recurso extraordinário a que se nega provimento. (BRASIL. Supremo Tribunal Federal. Recurso Extraordinário com Agravo no 709.212/DF, Tribunal Pleno. Recorrente: Banco do Brasil S/A. Recorrida: Ana Maria Movilla de Pires e Marcondes. Relator: Min. Gilmar Mendes. Brasília, 13 de novembro de 2014. Disponível em: $<$ http://www.stf.jus.br/portal/processo/verProcessoPeca.asp?id=301000550\&tipoApp=.pdf>. Acesso em: 13 jul. 2016).

35 “[...] GARANTIA FUNDAMENTAL (CF, ART. 5ㅇ, INCISO LXXI). DIREITO DE GREVE DOS SERVIDORES PÚBLICOS CIVIS (CF, ART. 37, INCISO VII). EVOLUÇÃO DO TEMA NA JURISPRUDÊNCIA DO SUPREMO TRIBUNAL FEDERAL [...]" (BRASIL. Supremo Tribunal Federal. Mandado de Injunção no 670/ES, Tribunal Pleno. Impetrante: SINDPOL - Sindicato dos Servidores Policiais Civis do Estado do Espírito Santo. Impetrado: Congresso Nacional. Relator: Min. Gilmar Mendes. Brasília, 25 de outubro de 2007. Disponível em: $<$ http://www.stf.jus.br/portal/processo/verProcessoTexto.asp?id=2227935\&tipoApp=RTF>. Acesso em: 13 jul. 2016).
} 
sustentável, a necessidade de os riscos de desastres serem levados a sério no planejamento urbanístico (SUN, 2011, p. 2157-2201).

Neste cenário atual, desregulamentado, os Planos acabam servindo apenasde elementos de instrução a serem avaliados no processo de confecção de Planos Diretores Urbanísticos, gerando efeitos urbanísticos apenas após a sua integração no planejamento urbanístico. Em termos práticos, a ausência de regulamentação acarreta na sobreposição do Plano Diretor sobre as informações dos Planos de Bacia em termos urbanísticos, sendo que, no caso da futura expedição da regulamentação e instituição do cadastro, haverá um dever das municipalidades em internalizarem as informações urbanísticas e de áreas de riscos de desastres constantes nos Planos de Bacia e Mapas de Risco. Em qualquer dos cenários, havendo o conhecimento do risco de desastres e a omissão estatal, tem-se a possibilidade de responsabilização civil do Estado por omissão.

Num cenário pós-regulamentação do cadastro de municípios suscetíveis a desastres, haverá uma sadia plenitude de eficácia às orientações urbanísticas do novo sistema de proteção e defesa civil. Um modelo regulamentado estabelecerá o dever imediato de incorporação cogente de medidas para a prevenção, mitigação e redução de riscos naturais no planejamento territorial. Este dever de incorporação acarretará num saudável afastamento da noção do Plano Urbanístico "como instrumento de exclusiva racionalização dos fenômenos de crescimento urbano e de reorganização das estruturas urbanísticas e territoriais, desatendo aos riscos a que expõe os destinatários das normas urbanísticas" (PAULA OLIVEIRA; LOPES, 2012, p. 176). A superação de uma matriz urbanística centrada apenas a partir de um viés mercadológico (colocando o retorno financeiro na frente dos princípios básicos da boa urbanidade (NUNES; ROSA; MORAES, 2015, p. 6)) e de uma circunvisão limitada territorialmente ao município é o nítido objeto dos deveres impostos pela Política Nacional de Proteção e Defesa Civil. Os Planos de Recursos Hídricos, neste cenário, têm a função de inserir uma dimensão regional, um modelo mais amplo de gestão e de governança na ordenação territorial.

No cenário regulamentado, há o dever de estreita compatibilização dos Planos Diretores aos resultados e orientações dos Planos de Recursos Hídricos, sendo que a omissão a este dever de absorção pode gerar responsabilidades pessoais dos gestores bem como, por evidente, do ente estatal municipal por omissão que tenha redundado em prejuízos e perdas por desastres.

A atual ausência de regulamentação tem efeito direto e imediato de estabelecer uma insegurança jurídica e imprecisão acerca do perfil do que seriam "áreas suscetíveis à ocorrência de 
deslizamentos de grande impacto, inundações bruscas ou processos geológicos ou hidrológicos correlatos". Lembre-se que o cadastro a ser regulamentado consiste no pressuposto para incidência de todos os artigos que trazem efeitos urbanísticos diretos pela Lei no 12.608/12. Como consequência, apesar destes eventos extremos serem passíveis de descrição e conhecidos, uma regulamentação teria a função de padronizara incidência dos deveres de prevenção em como de criar critérios bem definidos para a determinação da intensidade ou frequência necessárias para estes eventos serem considerados desastres no escopo de produzir restrições urbanísticas.

Ainda, a ausência de regulamentação repercute na manutenção de uma indesejável e desnecessária discricionariedade, no que toca o dever de compatibilizar o Plano Diretor com o Plano de Bacia Hidrográfica. Num sistema regulamentado, a ausência de integração de um Plano Diretor pelo legislativo municipal poderia redundar em demanda judicial com tal finalidade (alteração do Plano Diretor por ordem judicial). No sistema desregulamentado, contudo, inexiste esta possibilidade, cabendo apenas a proibição de emissões de licenças ambientais ou urbanísticas $^{36}$ pelos órgãos da administração pública para atividades a serem desenvolvidas em áreas de risco (descritas por Planos de Bacia ou mapas de risco) bem como a possibilidade de responsabilização civil do município por omissão em caso de ocorrência de um desastre. Em ambos os casos, o fator preponderante para tais limitações urbanísticas é o conhecimento antecipado do risco, este trazido por diagnósticos que permeiam quer Planos de Bacia quer mapas de risco de desastres.

De outro lado, ante a inexistência atual de um cadastro formalmente regulamentado pelo órgão competente, todos os textos e inovações de cunho urbanístico trazidos pela Política Nacional de Proteção e Defesa Civil ficam com sua plenitude eficacial suspensa.

Não obstante a desregulamentação, segue vigendo de forma plena o dever geral imposto no art. 8ㅇ, IV e V da Lei no12.608 (BRASIL, 2012), determinando um dever direcionado aos municípios para que estes mapeiem seus riscos e evitem novas ocupações em áreas de riscos (deslizamentos de grande impacto, inundações bruscas ou processos geológicos ou hidrológicos correlatos). Note-se que a incidência deste artigo não depende da regulamentação dos cadastros acima explicitada. Destarte, apesar dos artigos que operacionalizam este dever (com deveres mais específicos) não estarem regulamentados e, por isto, encontrarem-se em suspenso, este dever geral segue com eficácia plena.

${ }^{36}$ Como bem adverte MACHADO (2016, p. 540): "Aprovado o Plano de Recursos Hídricos, ele deverá ser respeitado no momento do licenciamento ambiental, desde que não contrarie expressamente a legislação ambiental a ser aplicada pelos órgãos licenciadores". 
Quanto à magnitude de um evento para justificar a imposição de restrições, estes devem ser avaliados a partir de históricos locais ou regionais, principalmente pela frequência de ocorrências e sua intensidade. Ainda, o conhecimento do risco, capaz de gerar deveres de prevenção, pode decorrer do conhecimento científico dos riscos, em virtude de sua previsão em medidas não estruturais (Planos de Bacia Hidrográfica, mapas de risco, Estudos de Impacto Ambiental - EIA, entre outros). De tal sorte, áreas suscetíveis a tais eventos geram o dever de serem mapeadas (art. 8o, IV, Lei no 12.608/12), assim como a municipalidade tem o dever geral de fiscalizar e vedar novas ocupações (art. 8oㅡ, V, Lei no 12.608/12). A desobediência a estes deveres gera a possibilidade de medidas judiciais ou administrativas preventivas bem como ações compensatórias por danos.

\section{CONSIDERAÇÕES FINAIS}

O presente trabalho parte de uma premissa bem definida de que os Planos Diretores em geral (no caso deste texto, em especial, Urbanísticos, de Recursos Hídricos e de Contingência) apresentam um caráter multifacetado. Tais instrumentos apresentam um conteúdo científico, descrevendo diagnósticos, cenários, metas, restrições e programas. Estes instrumentos de planejamento apresentam, ainda, uma função de uso político, exercendo um papel fundamental na gestão pública. Não bastassem tais funções, estes instrumentos de planejamento adquirem força jurídica, restringindo a amplitude das decisões disponíveis pelo Poder Público (poder discricionário), em virtude de sua previsão legal e do império do Direito na garantia da boa governança (good governance) da coisa pública.

O cenário de intensificação de eventos climáticos extremos enaltece a necessidade de maior atenção a estes instrumentos, face ao seu conteúdo de antecipação e planejamento setorial. No caso brasileiro, os eventos climáticos que causam maiores perdas humanas e patrimoniais consistem nas inundações, merecendo um destaque da legislação a necessária compatibilização entre os Planos Diretores Urbanísticos e os Planos de Bacia Hidrográfica. Primeiramente, enquanto que o cerne dos Planos Diretores Urbanísticos é a gestão territorial municipal, os Planos de Bacia centram suas análises na gestão dos recursos hídricos. Contudo, não raras vezes há uma influência determinante das formas de ocupação e uso do solo sobre a qualidade dos recursos hídricos, inclusive no que toca o incremento da vulnerabilidade, física ou social, de comunidades a riscos de desastres (em especial, inundações, deslizamentos de massa, ventos fortes, acidentes industriais). Não por outra razão, a recente Política Nacional de Proteção e Defesa Civil realizou a alteração de 
diversos dispositivos legais de conteúdo urbanístico e gestão territorial em outros diplomas legais (tais como o Estatuto das Cidades e Lei de Parcelamento do Solo Urbano).

Numa conclusão preliminar, nota-se a existência de um dever de proteção que estabelece ser competência dos municípios em identificar e mapear as áreas de risco, devendo ser fiscalizadas e vedadas novas ocupações, nos termos previstos no art. 8ㅇ, incisos IV e V da Lei 12.608/12. Devese chamar a atenção para o fato deste dever estar em sua plenitude eficacial, não havendo qualquer restrição para sua aplicabilidade.

Infelizmente, o mesmo não pode ser constatado para os deveres secundários, mais delimitados para fins urbanísticos e de planejamento territorial, face à sua dependência legal de regulamentação pelo Poder Público Federal, o que não ocorreu até o presente momento. Por evidente, tal situação retira a plena exequibilidade de todos os dispositivos que façam menção ao Cadastro Nacional de Municípios com Áreas Suscetíveis à Ocorrência de Deslizamentos de Grande Impacto, Inundações Bruscas ou Processos Geológicos ou Hidrológicos como conditio juris da plenitude eficacial normativa destes textos legais. Até lá, permanece suspensa a eficácia de tais dispositivos normativos, os quais em grande parte operacionalizam o dever geral de mapeamento e da fiscalização de áreas de risco cabíveis ao município (exigidos em dever geral no art. 8o, IV e V, Lei no 12.608/12).

O principal aspecto da regulamentação de lei consiste em definir a estruturação do cadastro referido pela lei, especialmente delimitando perfis, padrões e critérios para a caracterização de eventos que tornem os municípios suscetíveis aos deveres impostos de forma mais específica para cumprimento do dever geral. Assim, apenas para demonstrar a relevância da necessária regulamentação, destacam-se alguns dos deveres específicos impostos e hoje condicionados a esta: i) elaborar o mapeamento nas áreas suscetíveis a tais riscos a partir de cartas geotécnicas; ii) elaborar Plano de Contingência; iii) criar mecanismos de controle e fiscalização para evitar a edificação em áreas suscetíveis a tais desastres; iv) identificadas áreas de risco, adotar providências para sua redução, dentre as quais a execução do plano de contingência e de obras de segurança e, quando necessário, remoção de edificações e reassentamento; v) exigir plano diretor independentemente do número de habitantes.

A questão aqui colocada é juridicamente delicada, pois as restrições impostas pelo sistema urbanístico determinado após a promulgação da Política Nacional de Proteção e Defesa Civil (especialmente nas alterações realizadas por esta, na Lei no 10.257/01, na Lei no 12.340/10 e na Lei no 6.766/79) encontram-se condicionadas à regulamentação do referido cadastro nacional. 
Considerando a importância dos deveres específicos impostos aos municípios e atualmente suspensos em virtude de seu condicionamento à regulamentação de cadastro nacional, tem-se que esta é uma omissão regulamentar grave, cabendo mandado de injunção. Apenas para se ter uma dimensão, destaca-se mais alguns destes deveres específicos suspensos pela ausência de regulamentação do cadastro nacional: i) a necessidade de tomada de consideração do conteúdo dos mapas de risco nos Planos Diretores; ii) adoção de medidas de drenagem urbana necessária urbana necessárias à prevenção e à mitigação de impactos de desastres; iii) compatibilização dos Planos Diretores Urbanísticos às disposições do Plano de Recursos Hídricos; iv) necessidade de condicionamento da ampliação de perímetro urbano à apresentação de projeto específico que contenha, dentre outros fatores, a delimitação dos trechos com restrição à urbanização e dos trechos sujeitos a controle especial em função de ameaça de desastres naturais; v) vinculação da aprovação de projetos de loteamento e desmembramento ao atendimento dos requisitos apresentados pelas cartas geotécnicas.

Por evidente, tais tarefas podem e devem ser exercidas pelo município, porém, não há um caráter protestativo específico para tais deveres, nem mesmo para sua necessária internalização no Plano Diretor Urbanístico, até que haja a regulamentação do referido cadastro nacional. Uma das principais lacunas num cenário desregulamentado é exatamente a delimitação de quais municípios deveriam estar sujeitos a tais restrições, cabendo o questionamento de qual seria a intensidade e/ou frequência necessária na ocorrência de um desastre para gerar o dever de inserção de um município no referido cadastro e sua consequente submissão ao seu regime. Contudo, a ocorrência frequente de eventos extremos e suas respectivas perdas, indubitavelmente, deve gerar deveres de prevenção, mesmo em um cenário desregulamentado. Em especial, como visto no presente trabalho, este conhecimento histórico do risco gera o dever geral de mapeamento dos riscos (que podem estar previstos em diversos instrumentos, inclusive em um Plano de Bacia Hidrográfica), gerando este conhecimento o dever de preveni-los. Aqui notase, por evidente, uma ampla discricionariedade do Poder Público Municipal para a escolha de quais medidas deverão ser adotadas para este processo de prevenção de eventos futuros. Num cenário regulamentado, esta discricionariedade é reduzida sensivelmente.

Por evidente, os efeitos urbanísticos do Plano Diretor são diretos e imediatos, enquanto que os efeitos urbanísticos e na gestão do solo decorrentes dos diagnósticos dos Planos de Bacia Hidrográfica são indiretos e, necessariamente, dependem da mediação ou internalização pelos primeiros. Os deveres acima descritos delimitam especificamente como os municípios devem agir 
na ordenação do solo para prevenção de desastres. Porém, a ausência de regulação prejudica a força normativa destes dispositivos. Considerando o fato de que o risco de prejuízos extremos decorrentes da expansão urbana para áreas vulneráveis, as restrições urbanísticas previstas na legislação dependem da regulamentação do chamado Cadastro Nacional de Municípios com Áreas Suscetíveis à Ocorrência de Deslizamentos de Grande Impacto, Inundações Bruscas ou Processos Geológicos ou Hidrológicos.

Apesar da ausência de regulação, há persistência de deveres gerais relevantes, tais como o dever de identificar e mapear os riscos de desastres, bem como promover a fiscalização e vedar novas ocupações nestas áreas. Da mesma forma, persiste a proibição na concessão de licença ou alvará de construção em áreas de risco indicadas como não edificáveis no Plano Diretor ou legislação dele derivada.

Assim, a ausência de regulamentação aumenta uma indesejável insegurança jurídica, uma vez que não esclarece os múltiplos critérios possíveis a serem utilizados para delimitar quais são os municípios sujeitos a tais restrições. Contudo, não se pode olvidar que os dados e diagnósticos existentes nos Planos de Bacia ou outros documentos podem suprir esta função, por fornecerem o conhecimento do risco de desastres a que está sujeito um município. A partir desta constatação (pela incidência histórica de inundações, por exemplo), os textos normativos não regulamentados, e, portanto, suspensos, podem servir de parâmetro, porém, com sua normatividade suspensa. Mesmo num cenário desregulamentado, os planos setoriais devem ser tomados em consideração para a gestão territorial, enquanto que, após a regulamentação, as consequências legais já estão atribuídas para o caso dos municípios inclusos no cadastro.

Uma diferença central num cenário de ausência de regulamentação é a grave suspensão do dever direto de compatibilização do Plano Diretor ao conteúdo dos Planos de Bacia, permitindo uma maior discricionariedade no planejamento territorial municipal. Contudo, cumpre esclarecer que o conhecimento do risco pelo município indica não apenas o dever de identificação de riscos como a vedação de ocupação de novas áreas que se encontrem nesta condição de vulnerabilidade, sob pena de possível responsabilização civil do município por omissão, caso este não adote medidas cabíveis para a prevenção de desastres. 


\section{REFERÊNCIAS BIBLIOGRÁFICAS}

ASSOCIATION OF STATE FLOOD PLAIN MANAGERS (ASFPM). Floodplain management 2050: a report of the 2007 Assembly of the Gilbert F. White National Flood Policy Forum.Washington, 2007. Disponivel em: <http://www.asfpmfoundation.org/acefiles/forum/GFW_Forum_Report\%202050.pdf?pagename=forum/GFW_Forum_Report\%202050.pd f>. Acesso em: 13 jul. 2016.

ATLAS BRASILEIRO DE DESASTRES NATURAIS 1991 a 2010: VOLUME BRASIL. Florianópolis: CEPED UFSC, 2012.

BARROS, Mario Thadeu Leme de. Drenagem urbana: bases conceituais e planejamento. In: PHILIPPI JR., Arlindo (Ed.). Saneamento, saúde e ambiente: fundamentos para um desenvolvimento sustentável. São Paulo: Manole, 2005.

BINDER, Denis. Emergency action plans: a legal and practical blueprint failing to plan is planning to fail. University of Pittsburgh Law Review, 63, 2002.

BIRKLAND, Thomas A. Emergency management and courts in the wake of Hurricane Katrina. In: SARAT, Austin; LEZAUN, Javier (Ed.). Catastrophe: law, politics and the humanitarian impulse. University of Massachusetts Press, 2009.

BRASIL. Constituição (1988). Constituição da República Federativa do Brasil de 1988. Disponível em: <http://www.planalto.gov.br/ccivil_03/constituicao/ConstituicaoCompilado.htm>. Acesso em: 13 jul. 2016.

Lei Complementar no 140, de 08 de dezembro de 2011. Fixa normas, nos termos dos incisos III, VI e VII do caput e do parágrafo único do art. 23 da Constituição Federal, para a cooperação entre a União, os Estados, o Distrito Federal e os Municípios nas ações administrativas decorrentes do exercício da competência comum relativas à proteção das paisagens naturais notáveis, à proteção do meio ambiente, ao combate à poluição em qualquer de suas formas e à preservação das florestas, da fauna e da flora; e altera a Lei no 6.938, de 31 de agosto de 1981. Disponível em: <http://www.planalto.gov.br/ccivil_03/leis/LCP/Lcp140.htm>. Acesso em: 13 jul. 2016.

Lei no 10.257, de 10 de julho de 2001. Regulamenta os arts. 182 e 183 da Constituição Federal, estabelece diretrizes gerais da política urbana e dá outras providências. Disponível em: <http://www.planalto.gov.br/ccivil_03/leis/LEIS_2001/L10257.htm>. Acesso em: 13 jul. 2016.

Lei no 12.340, de 10 de dezembro de 2010. Dispõe sobre as transferências de recursos da União aos órgãos e entidades dos Estados, Distrito Federal e Municípios para a execução de ações de prevenção em áreas de risco de desastres e de resposta e de recuperação em áreas atingidas por desastres e sobre o Fundo Nacional para Calamidades Públicas, Proteção e Defesa Civil; e dá outras providências. Disponível em: <http://www.planalto.gov.br/ccivil_03/_ato20072010/2010/lei/l12340.htm>. Acesso em: 13 jul. 2016.

Lei no 12.608, de 10 de abril de 2012. Institui a Política Nacional de Proteção e Defesa Civil PNPDEC; dispõe sobre o Sistema Nacional de Proteção e Defesa Civil - SINPDEC e o Conselho Nacional de Proteção e Defesa Civil - CONPDEC; autoriza a criação de sistema de informações e monitoramento de desastres; altera as Leis nos 12.340, de 1 o de dezembro de 2010, 10.257, de 10 de julho de 2001, 6.766, de 19 de dezembro de 1979, 8.239, de 4 de outubro de 1991, e 9.394, de 20 de dezembro de 1996; e dá outras providências. Disponível em: < 
http://www.planalto.gov.br/ccivil_03/_Ato2011-2014/2012/Lei/L12608.htm>. Acesso em: 13 jul. 2016.

Lei no 12.651 , de 25 de maio de 2012. Dispõe sobre a proteção da vegetação nativa; altera as Leis nos 6.938, de 31 de agosto de 1981, 9.393, de 19 de dezembro de 1996, e 11.428, de 22 de dezembro de 2006; revoga as Leis nos 4.771, de 15 de setembro de 1965, e 7.754, de 14 de abril de 1989, e a Medida Provisória no 2.166-67, de 24 de agosto de 2001; e dá outras providências. Disponível em: <http://www.planalto.gov.br/ccivil_03/_ato2011-2014/2012/lei//12651.htm>. Acesso em: 13 jul. 2016.

Lei no 6.766, de 19 de dezembro de 1979. Dispõe sobre o Parcelamento do Solo Urbano e dá outras Providências. Disponível em: <http://www.planalto.gov.br/ccivil_03/leis/L6766.htm>. Acesso em: 13 jul. 2016.

Lei no 9.433, de 08 de janeiro de 1997. Institui a Política Nacional de Recursos Hídricos, cria o Sistema Nacional de Gerenciamento de Recursos Hídricos, regulamenta o inciso XIX do art. 21 da Constituição Federal, e altera o art. 10 da Lei no 8.001, de 13 de março de 1990, que modificou a Lei no 7.990, de 28 de dezembro de 1989. Disponível em: <http://www.planalto.gov.br/ccivil_03/leis/L9433.htm>. Acesso em: 13 jul. 2016.

Ministério do Meio Ambiente; GOVERNOS LOCAIS PELA SUSTENTABILIDADE (ICLEI). Orientações para elaboração dos planos. In: BRASIL. Ministério do Meio Ambiente; GOVERNOS LOCAIS PELA SUSTENTABILIDADE (ICLEI). Planos de gestão de resíduos sólidos: manual de orientação. Apoiando a implementação da política nacional de resíduos sólidos: do nacional ao local. Brasília, DF, 2012. p. 31-63. Disponível em: <http://www.mma.gov.br/estruturas/182/_arquivos/manual_de_residuos_solidos3003_182.pdf>. Acesso em: 13 jul. 2016.

Supremo Tribunal Federal. Mandado de Injunção no 670/ES, Tribunal Pleno. Impetrante: SINDPOL - Sindicato dos Servidores Policiais Civis do Estado do Espírito Santo. Impetrado: Congresso Nacional. Relator: Min. Gilmar Mendes. Brasília, 25 de outubro de 2007. Disponível em: $<$ http://www.stf.jus.br/portal/processo/verProcessoTexto.asp?id=2227935\&tipoApp=RTF>. Acesso em: 13 jul. 2016.

Supremo Tribunal Federal. Recurso Extraordinário com Agravo no 709.212/DF, Tribunal Pleno. Recorrente: Banco do Brasil S/A. Recorrida: Ana Maria Movilla de Pires e Marcondes. Relator: Min. Gilmar Mendes. Brasília, 13 de novembro de 2014. Disponível em: <http://www.stf.jus.br/portal/processo/verProcessoPeca.asp?id=301000550\&tipoApp=.pdf>. Acesso em: 13 jul. 2016.

CARDOSO, Fernando Henrique. Notas sobre a reforma do Estado. Revista Novos Estudos Cebrap. São Paulo, n. 50, 1998.

CARVALHO, Délton Winter de. Desastres ambientais e sua regulação jurídica: deveres de prevenção, resposta e compensação ambiental. São Paulo: Revista dos Tribunais, 2015.

CARVALHO, Délton Winter de; DAMACENA, Fernanda Dalla Libera. Direito dos desastres. Porto Alegre: Livraria do Advogado, 2013.

CONSELHO NACIONAL DE RECURSOS HÍDRICOS. Resolução no 05, de 11 de abril de 2000. Disponível em: <http://www.cbh.gov.br/legislacao/20000410_CNRHRes005_DiretrizesCBH.pdf>. Acesso em: 13 jul. 2016. 
FARBER, Daniel A. Disaster Law in the Anthropocene. In: PEEL, Jacqueline; FISHER, David (Eds.). The Role of International Environmental Law in Disaster Risk Reduction. Boston: BrillNijhoff, 2016.

FARBER, Daniel; CHEN, Jim; VERCHICK, Robert; SUN, Lisa Grow. Disaster Law and Policy. New York: Aspens Publishers, 2010.

FARIA, José Eduardo (Org.). Regulação, direito e democracia. São Paulo: Fundação Perseu Abramo, 2002.

GRAZIERA, Maria Luiza Machado. Direito de águas: disciplina jurídica das águas doces. 3. ed. São Paulo: Atlas, 2006.

KRIEGER, Maria da Graça; MACIEL, Anna Maria B.; ROCHA, João Carlos de C.; FINATTO, Maria José B.; BEVILACQUA, Cleci Regina. Dicionário de Direito Ambiental: terminologia das leis do meio ambiente. 2. ed. Rio de Janeiro: Lexikon, 2008.

MACHADO, Paulo Affonso Leme. Direito ambiental brasileiro. 24 ed. São Paulo: Malheiros, 2016.

MEIRELLES, Hely Lopes. Direito administrativo brasileiro. 41. ed. São Paulo: Malheiros, 2015.

MELLO, Celso Antônio Bandeira de. Curso de direito administrativo. 25. ed. São Paulo: Malheiros, 2008.

MICHAELIS: Moderno Dicionário da Língua Portuguesa. Companhia Melhoramentos, 1998.

NUNES, Tarcisio; ROSA, Júnia Santa;MORAES, Rayne Ferretti (Org.). Sustentabilidade urbana: impactos do desenvolvimento econômico e suas consequências sobre o processo de urbanização em países emergentes: textos para as discussões da Rio+20. Brasília, DF: Ministério do Meio Ambiente, 2015. v. 3: Habitação social e sustentabilidade urbana.Disponível em: <file:///F:/volume3_habitacao_social.pdf>. Acesso em: 13 jul. 2016.

MINISTÉRIO PÚBLICO FEDERAL (MPF). MPF cobra criação do cadastro nacional de municípios em áreas de risco e funcionamento do serviço 199. Rio de Janeiro, abril 2014. Disponível em: $<$ http://www.prrj.mpf.mp.br/frontpage/noticias/mpf-cobra-criacao-do-cadastro-nacional-demunicipios-em-areas-de-risco-e-funcionamento-do-servico-199>. Acesso em: 13 jul. 2016.

PAULA OLIVEIRA, Fernanda; LOPES, Dulce. Catástrofes naturais e Direito do Urbanismo. In: GOMES, Carla Amado (Coord.). Direito(s) das catástrofes naturais. Coimbra: Almedina, 2012.

RINDEBRO, U. Natural Disasters Likely to Become More Frequent, Costly - Swiss Re - Brazil. Business News Americas. 2011. Disponível em: <http: //www. bnamericas. $\mathrm{com} /$ news/insurance/natural-disasters-likely-to-become-more-frequent-costly-swiss-re>. Acesso em: 13 jul. 2016.

SARLET, Ingo Wolfgang; MACHADO, Paulo Affonso Leme; FENSTERSEIFER, Tiago. Constituição e legislação ambiental comentadas. São Paulo: Saraiva, 2015.

SUN, Lisa Grow. Smart growth in dumb places: sustainability, disaster, and the future of the American city. BYU Law Review, 2011. 
VERCHICK, Robert R. M. Facing catastrophe: environmental action for a post-Katrina world. Cambridge: Harvard University Press, 2010.

Trabalho enviado em 13 de julho de 2016. Aceito em 06 de setembro de 2016. 